九州大学学術情報リポジトリ

Kyushu University Institutional Repository

\title{
Tree Ring Analysis for Growth Pattern and Age Structure of the Subtrophic Broad-leaved Forest in Taiwan
}

Chan, Ming-Hsun

Department of Forestry and Natural Resources, College of Agriculture, National Chiayi University

Chen, Jin-Hau

School of Forestry and Resource Conservation, National Taiwan University

Lin, Han Chien

Department of Forest Products Science, college of Agriculture, National Chiayi University

Fuj imoto, Noboru

Laboratory of Wood Material Technology, Division of Sustainable Bioresources Science,

Department of Agro-environmental Sciences, Faculty of Agriculture, Kyushu University

https://doi.org/10.5109/20327

出版情報: 九州大学大学院農学研究院紀要. 56 (2), pp.317-326, 2011-09. 九州大学大学院農学研究院 バージョン：

権利関係 : 


\title{
Tree Ring Analysis for Growth Pattern and Age Structure of the Subtrophic Broad-leaved Forest in Taiwan
}

\author{
Ming-Hsun CHAN ${ }^{1 *}$, Jin-Hau CHEN ${ }^{2}$, Han Chien LIN $^{3}$ \\ and Noboru FUJIMOTO ${ }^{4}$
}

\author{
Laboratory of Wood Material Technology, Division of Sustainable Bioresources Science, \\ Department of Agro-environmental Sciences, Faculty of Agriculture, \\ Kyushu University, Fukuoka 812-8581, Japan \\ (Received April 28, 2011 and accepted May 9, 2011)
}

\begin{abstract}
In this study, age structure, dynamics and growth pattern of subtropical forest located in central Taiwan were analyzed. The existence of annual rings in the wood of trees was proven by cross-dating and tree ring analysis. 218 individuals which belong to 27 species were investigated in the 0.71 ha plot of Shenmu evergreen broad-leaved forest. It indicates that the age of the trees correlates not strongly with the diameter and the height, while the mean diameter growth rates vary between $0.48 \mathrm{~cm}$ per year in understory tree species and $0.76 \mathrm{~cm}$ per year in emergent species. Compared with the main canopy tree species in Costa Rica's tropical forest, the mean annual diameter growth rate $0.66 \mathrm{~cm}$ is greater than that of $0.42 \mathrm{~cm}$. Stand dynamic of DBH and age structure fitted by Weibull function indicate that they are in medium status of forest regeneration, but the age's shape parameter $r=1.2$ is much close to 1 which stands for the limit boundary of very good regeneration status. The mean age for all individuals is 61 years. According to the age, height distribution and growth rate of the trees, we classify four major types of life strategies and the growth pattern of specie cohorts. These findings lead to the assumption that the investigated stand can be classified as a very late secondary stand in transition to a mature forest. The results also reveal that it is a valuable tool for estimations of growth rate and pattern by using tree ring analysis in subtropical evergreen forest ecology.
\end{abstract}

Keywords: Evergreen Broad-leaved Forest, Subtropics, Age Structure, Growth Pattern, Tree Ring Analysis

\section{INTRODUCTION}

The fact of extensive logging natural broad-leaved forests in tropical or subtropical area has become an important worldwide issue on the topic of sustainable forest management. However, knowledge related to the forest dynamics and productivity of natural broad-leaved forests stand is scarce, not to mention the condition and growth rate. Besides, the knowledge of growth rates of tropical or subtropical trees under natural conditions is rather poor. Estimates are vague and vary considerably depending on the methods used. For decades, a great deal of researches on the topic of the growth and dynamics of natural forests in the temperate zone and longterm monitoring and investigation at parts of the zone were made by scientists (Koop, 1989). In contrast with the previous studies, there are very few researches related to the development of tropical and subtropical natural forest stand. In terms of biomass study, when taking $60 \mathrm{~cm}$ as a benchmark for diameter at breast height $(\mathrm{DBH})$, it is found that the growth rates of tropical for-

${ }^{1}$ Department of Forestry and Natural Resources, College of Agriculture, National Chiayi University, Chiayi, Taiwan, ROC

${ }^{2}$ School of Forestry and Resource Conservation, National Taiwan University, Taipei, Taiwan, ROC

${ }^{3}$ Department of Forest Products Science, College of Agriculture, National Chiayi University, Chiayi, Taiwan, ROC

${ }^{4}$ Laboratory of Wood Material Technology, Division of Sustainable Bioresources Science, Department of Agroenvironmental Sciences, Faculty of Agriculture, Kyushu University, Japan

* Corresponding author (E-mail: mhchan@mail.ncyu.edu.tw) ests are lower than that of the temperate zone such as birch woods in the land of Canada (Ellenberg, 1986).

Until now, only a few tropical or subtropical natural forests have been observed for a long period of time. In these areas, the forest growth rate and dynamics are attained by averaging the cumulated figures which are obtained by repeatedly measuring tree diameter (Lieberman et al., 1985). Basically, this means of research can only be attained by long-term investigation, which gathers long-term data for diagnosis. Dendrochronology has been applied in reconstructing the stand history in the temperate zone (Abrams of M.D. and Orwig, 1995; Koop, 1989; Worbes, 1989; Worbes, 1995) but has not been applied to tropical or subtropical forests due to the common, yet erroneous assumption that tropical stand lack annual ring. (Lang and Knight, 1983; Lieberman et al., 1985; Whitmore, 1990) However, many species of tropical forests with a distinct and predicable dry season have annual rings. In general, deciduous broad-leaved species growing in subtropical areas have distinguishable tree rings; evergreen broad-leaved species growing at sites $1000 \mathrm{~m}$ above sea level form annual rings in winter when it is cold and dry. The global distribution of forest region exceeds the size of rainforests of the equator. There are many tree species in the forests in western African lowlands that provide tree ring analysis (Amobi, 1973; Msrisux, 1970; Msrisux, 1981). These studies, when applied with dendrochronology, may help the analysis of condition as well as the managing of forests in tropical or subtropical zones.

The Tropic of Cancer passing through the central part of Taiwan; therefore, the northern part of the island 


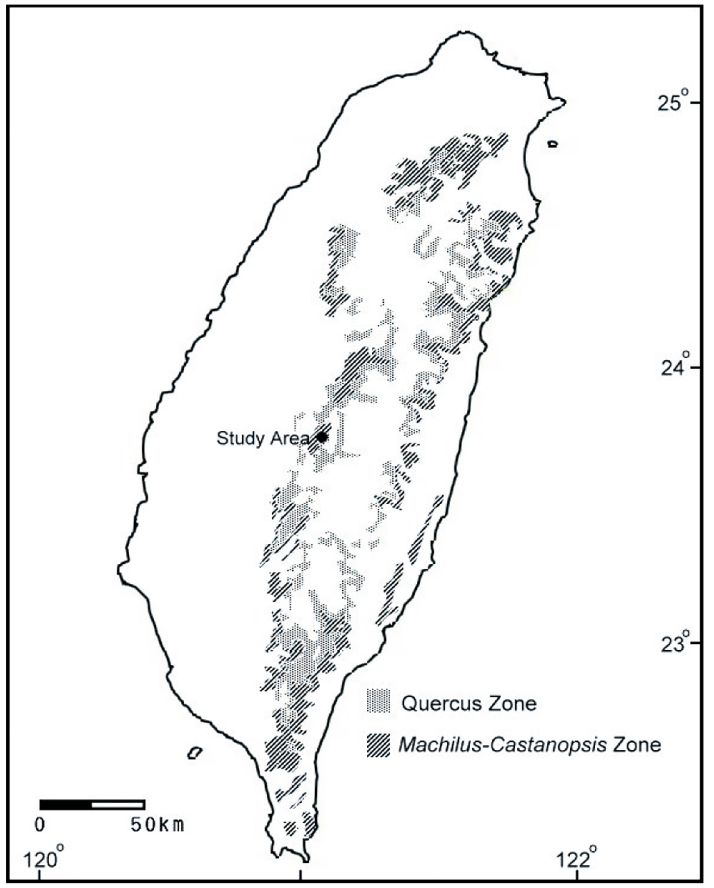

a

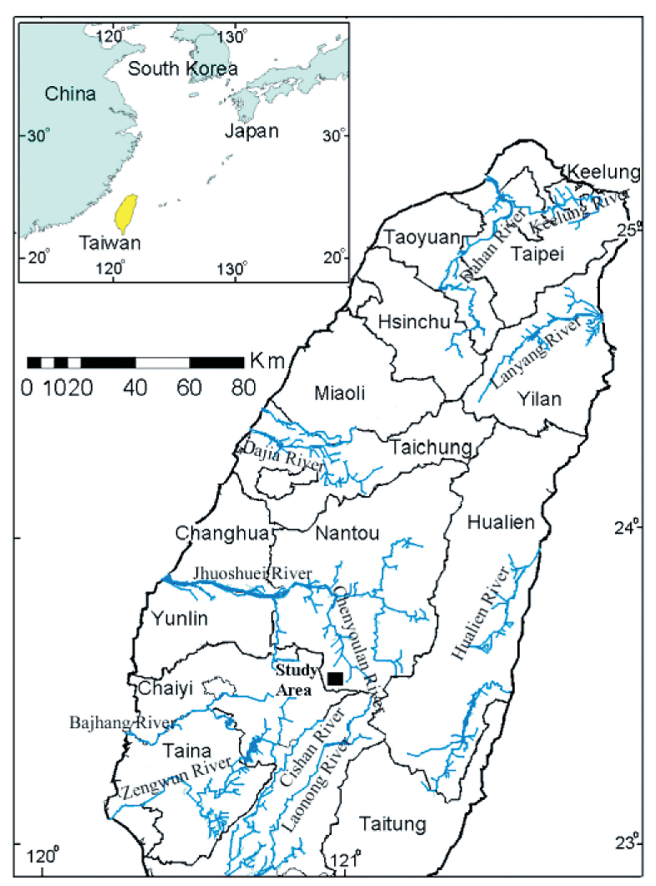

b

Fig. 1. (a) Distribution of Machilus-Castanopsis zone and Quercus zone in Taiwan; (b) Locations of sample site in Shenmu Broad-leaved Conservation Forest.

is subtropical while the southern is tropical. The biological resources are abundant due the diverse distribution of terrain both in horizontal and in perpendicular elevation. Vegetation zones in Taiwan can be divided the forest types into different climate zones. Temperature varies greatly from the tropical and subtropical and cold temperature (Su, 1984). Shenmu Broad-leaved Conservation Forest (SBCF) is located in the subtropical evergreen broad-leaved forest zone and can be considered as a representative area. The Machilus-Castanopsis zone extends from 500 meters to 1500 meters and with subtropical climate in Taiwan (Fig. 1a). The major forest types are Beilschmiedia erythrophloia-Turpinia formosana, Alnus formosana-Villebrunea pedunculata, Beilschmiedia erythrphloia-Machilus japonicaTurpinia formosana, Persea japonica-Machilus formosana, and Litsea acuminata-Michelia compressa.
In this study we prove the existence of annual rings in trees of a natural forest stand in SBCF, a subtropical seasonal evergreen broad-leaved forest in Taiwan. We use tree ring analysis for reconstructing stand history and growth pattern of important species, and estimating the diameter growth of the trees in this stand. The study is to show how tree ring analysis is helpful to evaluate basic data for the management of subtropical forests.

\section{MATERIALS AND METHODS}

\section{Site description}

The study site is located at southern part of Shenmu village, Sin-Yi township of Nan-Tou County in Central Taiwan (Fig. 1a). The Shenmu Broad-leaved Conservation Forest (SBCF) area $\left(23^{\circ} 35^{\prime} \mathrm{N}, 120^{\circ} 53^{\prime} \mathrm{E}\right)$ is belonged to $31^{\text {st }}$ compartment of Tui-Kao-Yao tract, gov-

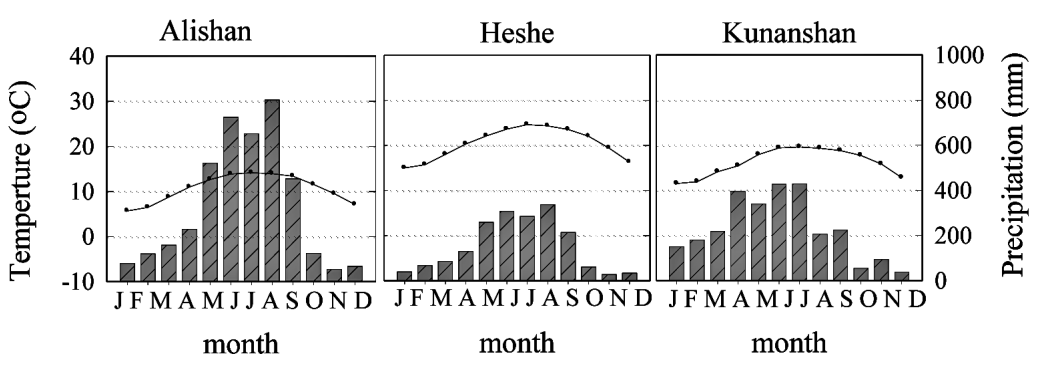

Fig. 2. Monthly mean temperature (curve) and monthly total precipitation (bar) at the three meteorological stations (Alishan meteorological observatory 1935$1995,23^{\circ} 30^{\prime} \mathrm{N}, 120^{\circ} 48^{\prime} \mathrm{E}$ Alt. 2415 m, Heshe meteorological observatory 1994 $200423^{\circ} 35^{\prime} \mathrm{N}, 120^{\circ} 53^{\prime} \mathrm{E}$ Alt. $750 \mathrm{~m}$ and Kunanshan meteorological observatory 1994-2004 2330'53" N, 12054'55"E Alt. 1700 m, attribute data from weather annual report of the Central Weather Bureau, Taiwan). 
Table 1. The soil $\mathrm{pH}$ value, soil texture and phosphorus of five plots from SBCF

\begin{tabular}{|c|c|c|c|c|c|c|c|}
\hline Plot ID & Soil dept (cm) & $\mathrm{pH}$ value & Sand (\%) & Silt (\%) & Clay (\%) & Soil texture & $\begin{array}{l}\text { Phosphorus } \\
\text { (total) (mg/g) }\end{array}$ \\
\hline \multirow[t]{3}{*}{3} & $0-5$ & $5.2 \pm 0.28$ & $50.5 \pm 0.71$ & $36.5 \pm 2.12$ & $13.0 \pm 1.41$ & standy loam & $0.20 \pm 0.10$ \\
\hline & $6-10$ & $5.2 \pm 0.92$ & $39.0 \pm 1.41$ & $40.5 \pm 2.12$ & $21.0 \pm 1.41$ & clay loam & $0.23 \pm 0.16$ \\
\hline & $11-15$ & $5.2 \pm 0.35$ & $33.0 \pm 4.24$ & $43.0 \pm 4.24$ & $24.0 \pm 0.00$ & clay loam & $0.20 \pm 0.17$ \\
\hline \multirow[t]{3}{*}{4} & $0-5$ & $5.3 \pm 0.64$ & $40.5 \pm 2.12$ & $38.5 \pm 6.36$ & $21.0 \pm 4.24$ & loam & $0.38 \pm 0.03$ \\
\hline & $6-10$ & $5.2 \pm 0.07$ & $37.0 \pm 1.41$ & $35.0 \pm 4.24$ & $28.0 \pm 5.66$ & clay loam & $0.30 \pm 0.15$ \\
\hline & $11-15$ & $5.4 \pm 0.21$ & $47.5 \pm 14.85$ & $35.5 \pm 4.95$ & $17.0 \pm 9.90$ & standy loam & $0.19 \pm 0.05$ \\
\hline \multirow[t]{3}{*}{5} & $0-5$ & $5.3 \pm 0.14$ & $39.0 \pm 4.24$ & $49.0 \pm 1.41$ & $12.0 \pm 2.83$ & loam & $0.34 \pm 0.17$ \\
\hline & $6-10$ & $5.3 \pm 0.42$ & $45.0 \pm 12.73$ & $46.0 \pm 11.31$ & $9.0 \pm 1.41$ & silty loam & $0.17 \pm 0.05$ \\
\hline & $11-15$ & $5.4 \pm 0.21$ & $47.5 \pm 14.85$ & $35.5 \pm 4.95$ & $17.0 \pm 9.90$ & silty loam & $0.19 \pm 0.05$ \\
\hline \multirow[t]{3}{*}{6} & $0-5$ & $4.6 \pm 0.99$ & $51.0 \pm 7.07$ & $36.0 \pm 2.83$ & $13.0 \pm 4.24$ & loam & $0.24 \pm 0.07$ \\
\hline & $6-10$ & $4.9 \pm 0.14$ & $37.0 \pm 7.07$ & $43.0 \pm 1.41$ & $20.0 \pm 5.66$ & silty loam & $0.13 \pm 0.03$ \\
\hline & $11-15$ & $4.7 \pm 0.49$ & $31.5 \pm 0.71$ & $42.5 \pm 4.95$ & $26.0 \pm 5.66$ & silty loam & $0.08 \pm 0.16$ \\
\hline \multirow[t]{3}{*}{7} & $0-5$ & $6.0 \pm 0.21$ & $62.0 \pm 32.53$ & $24.8 \pm 14.42$ & $13.2 \pm 18.10$ & silty loam & $0.08 \pm 0.03$ \\
\hline & $6-10$ & $5.9 \pm 0.14$ & $64.0 \pm 25.46$ & $27.0 \pm 15.56$ & $9.0 \pm 9.90$ & silty loam & $0.15 \pm 0.01$ \\
\hline & $11-15$ & $6.0 \pm 0.00$ & $55.5 \pm 16.26$ & $33.5 \pm 7.78$ & $11.0 \pm 8.49$ & silty loam & $0.21 \pm 0.06$ \\
\hline
\end{tabular}

erned by the Experiment Forest of National Taiwan University (Fig. 1b). The total area of SBCF is 167 ha with slope ranging from 30 and 45 degrees and altitude ranging between 1300 and $2200 \mathrm{~m}$.

In SBCF, an evergreen broad-leaved forest dominated by M. zuihoensis, B. erythrophloia, E. deflexa which are widely distributed over Taiwan (Fig. 1a). Climate data were obtained from the nearest climate station (Alishan, Heshe and Kuanshan) from the study site. Among the three stations, the longest observed precipitation and temperature time series at Alishan climate station extends from 1935 until the 1995. The climate is characterized by a mean annual precipitation of $3059 \mathrm{~mm}$ with a distinct seasonal distribution (Fig. 2). The dry season, with less than $150 \mathrm{~mm}$ precipitation per month, lasts from October to April. The temperature varies between $10.1^{\circ} \mathrm{C}$ in January and $20.0^{\circ} \mathrm{C}$ in July. The soil in SBCF mainly texture frequent silty loam, the $\mathrm{pH}$ value is between 4.6 and 6.0. The detail description of soil characteristics was listed in Table 1.

\section{Sampling, measurements and analyses}

The field work was carried out between February and July 2003. There are 5 sample plots of a natural forest with total area of 0.71 ha. Every single tree with a $\mathrm{DBH}>10 \mathrm{~cm}$ was orientated with its $\mathrm{x}$ and y coordinates (TWD67 system, a datum specified for Transversal Mercator Projection). The DBH was measured with a tape, and the height was measured trigonometrically with a SUUNTO measurement device. The DBH of trees with buttresses was measured above them.

In the investigation area from all trees with a $\mathrm{DBH}>10 \mathrm{~cm}$, two wood samples were taken at breast height along two rectangular radii with an increment corer $(\varnothing=5 \mathrm{~mm})$. In trees with buttresses, cores were taken from the stems portion between two buttresses.

The width and density of tree was archived by soft $\mathrm{X}$-ray image analysis methods and tree-ring measure- ments. The first tree-ring samples immersed with 98\% methanol solution, replacing the distillation until the solution was clean. Next step is to fix samples with glair gel and cut them into $2 \mathrm{~mm}$ thick, $5 \mathrm{~mm}$ width with a high accurate plane table saw. Finally, adjust the moisture of tree-ring samples to $12-15 \%$ in the thermostat that also has stable humidity. The second X-ray film image was then taken for image processing and analysis. The soft$\mathrm{X}$-ray machine $\left(\mathrm{HP}^{\circledR} \mathrm{CABINE} \mathrm{X}\right.$-ray system series Model 43855B) used in this study was made by Hewelett Packard. Two requests were made for the shooting: (1) $\mathrm{X}$-ray shooting distance set to $35 \mathrm{~cm}$ from the samples; the range of the negative film was $35 \mathrm{~cm} \times 43 \mathrm{~cm}(14$ in $\times$ 17in) $\left(\mathrm{KODAK}^{\circledast}\right.$ Industrex M100 film, 50 ready pack II); (2) the power of X-ray was $9 \mathrm{PkeV}, 3 \mathrm{~mA}$, for 50 minutes.

Finally, X-ray image was used to analyze tree-ring width and density of the cores samples by using five different software, as follows: Image Pro ${ }^{\circledR}$ Plus version 4.5 for Windows, Sigma Plot ${ }^{\circledR} 2001$ for Windows Version 7.0, Tsap Win Professional 0.23b Version 5.1, and Tree Ring $\mathrm{X}$-ray 32 Procedure integrating those software was developed by (Chan et al., 2004).

This procedure is usually applied in dendrochronological science for the detection of missing rings and termed cross-dating. Due to this procedure tree ring curves of all samples were corrected, including missing rings and excluding false rings. From the corrected curves, first the mean curve for every individual and mean curves for species in the second step were constructed.

Growth-ring dating was executed by incorporating the visioning method and statistic program analysis. Visually dating was done by the skeleton plot process and was done using Image-Pro ${ }^{\circledast}$ Plus. Ring widths were measured with a $0.02 \mathrm{~mm}$ precision at an $800 \mathrm{dpi}$ image. After that, cross-dating of the tree-ring series was achieved using dendrochronology program COFFECHA. This program has been well used to detect ring-width measurement and cross-dating error, and cores contain- 
ing such errors were corrected or removed from the data set.

Distributions of ecological phenomena are usually dependent on the environment and the interior factors of organism. For instance, regeneration status of vegetation might change along time series and it is possible to reveal exponential, normal, or skewed distribution. Regular distributions are so conditionally restricted and, therefore, not suitable for such needs. Fortunately, Weibull function is a versatile distribution and is one of the most widely used lifetime distributions in reliability engineering. It can take on the characteristics of other types of distributions based on the value of the shape parameter $\gamma$. Hence it is very convenient for ecological applications where the data distribution is unknown and needs to be empirically explored. Some researches about the analysis of forest diameter structure (Bailey and Dell, 1973; Lin et al., 2007; Tanouchi, 1995) have proven the powerful flexibility and suitability of Weibull function for ecological applications. Weibull function is

$$
\begin{aligned}
& \mathrm{f}(. ; ., ., .)=\frac{\gamma}{\beta} f(\chi ; \alpha, \beta, \gamma)=\frac{\gamma}{\beta}\left\{\left(\frac{x-\alpha}{\beta}\right) \gamma-1 e^{-}\left(\frac{x-\alpha}{\beta}\right) \gamma\right\} \\
& \text { Where } \\
& .=\text { location parameter, expressing the lower bound } \\
& .=\text { scale parameter }(.<0) \\
& .=\text { shape parameter }(.>0)
\end{aligned}
$$

\section{RESULTS}

\section{Species structure and composition}

A total number of 218 living trees with a DBH larger than $10 \mathrm{~cm}$ from 27 species was counted in the investigation area (0.71 ha). The majority of the species (11) have more than five individuals in the study plot and more frequent species are listed in Table 2. The majority of the individuals (54\%) belong to the understory up to $10-15 \mathrm{~m}$. The $30 \%$ of the individuals form the main canopy between 17 and $25 \mathrm{~m}$ and $16 \%$ of all trees can be classified as emergent with tree height up to $25 \mathrm{~m}$. The diameter distribution has an inverse J-shape with the

\begin{tabular}{|c|c|c|c|c|c|c|c|c|c|}
\hline Species & Family & $\mathrm{N}$ & $\begin{array}{l}\text { Wood } \\
\text { density } \\
\left(\mathrm{g} \mathrm{cm}^{-3}\right)^{\mathrm{a}}\end{array}$ & $\begin{array}{c}\text { Diameter } \\
\text { increment } \\
\left(\mathrm{cm} \mathrm{yr}^{-1}\right)^{\mathrm{a}}\end{array}$ & $\begin{array}{l}\text { Mean } \\
\text { height } \\
\text { (m) }\end{array}$ & $\begin{array}{l}\text { Max. } \\
\text { height } \\
\text { (m) }\end{array}$ & $\begin{array}{l}\text { Min. } \\
\text { age } \\
\text { (yr) }\end{array}$ & $\begin{array}{l}\text { Max. } \\
\text { age } \\
(y r)\end{array}$ & $\begin{array}{l}\text { Mean } \\
\text { age } \\
\text { (yr) }\end{array}$ \\
\hline \multicolumn{10}{|l|}{ Emergents } \\
\hline Alnus formosana & Betulaceae & 8 & $0.57 \pm 0.07$ & $0.68 \pm 0.18$ & 29.7 & 33.5 & 64 & 116 & 86 \\
\hline Cinnamomum camphora & Lauraceae & 3 & $0.60 \pm 0.10$ & $0.72 \pm 0.28$ & 28.7 & 32.0 & 68 & 256 & 133 \\
\hline Fraxinus formosana & Oleaceae & 23 & $0.79 \pm 0.11$ & $0.86 \pm 0.22$ & 27.0 & 39.0 & 27 & 131 & 62 \\
\hline Diospyros morrisiana & Ebenaceae & 3 & $0.69 \pm 0.04$ & $0.76 \pm 0.16$ & 25.2 & 31.5 & 22 & 184 & 88 \\
\hline \multicolumn{10}{|l|}{ Main canopy } \\
\hline Sloanea formosana & Elaeocaroaceae & 1 & 0.64 & 0.88 & 23.0 & 23.0 & 61 & 61 & 61 \\
\hline Machilus japonica var kusanoi & Lauraceae & 1 & 0.80 & 0.64 & 21.5 & 21.5 & 134 & 134 & 134 \\
\hline Machilus japonica & Lauraceae & 1 & 0.62 & 0.52 & 21.0 & 21.0 & 144 & 144 & 144 \\
\hline Machilus zuihoensis & Lauraceae & 52 & $0.70 \pm 0.15$ & $0.68 \pm 0.22$ & 20.0 & 35.5 & 17 & 119 & 52 \\
\hline Zelkova formosana & Ulmaceae & 3 & $0.94 \pm 0.03$ & $0.54 \pm 0.20$ & 18.3 & 23.5 & 33 & 55 & 42 \\
\hline Elaeocarpus sylvestris. & Elaeocarpaceae & 2 & $0.63 \pm 0.02$ & $0.72 \pm 0.02$ & 18.3 & 19.0 & 62 & 77 & 70 \\
\hline Acer albopurpurasxens & Aceraceae & 3 & $0.92 \pm 0.08$ & $0.70 \pm 0.06$ & 17.2 & 22.0 & 86 & 183 & 119 \\
\hline Cinnamomum insular-imontanum & Lauraceae & 3 & $0.69 \pm 0.03$ & $0.94 \pm 0.24$ & 17.0 & 23.0 & 35 & 49 & 43 \\
\hline Beilcschmiedia erythrophloia & Lauraceae & 36 & $0.84 \pm 0.11$ & $0.70 \pm 0.16$ & 16.4 & 25.0 & 23 & 122 & 55 \\
\hline Michelia compressa & Magnoliaxeae & 8 & $0.74 \pm 0.14$ & $0.62 \pm 0.16$ & 15.9 & 22.0 & 19 & 104 & 54 \\
\hline Phoebe formosana & Lauraceae & 7 & $0.67 \pm 0.07$ & $0.60 \pm 0.20$ & 15.9 & 21.5 & 30 & 65 & 45 \\
\hline Zanthoxylum ailanthoides & Rutaceae & 2 & $0.65 \pm 0.08$ & $0.98 \pm 0.02$ & 15.3 & 20.0 & 14 & 79 & 46 \\
\hline Litsea acuminata & Lauraceae & 34 & $0.72 \pm 0.13$ & $0.58 \pm 0.2$ & 15.1 & 32.5 & 28 & 185 & 56 \\
\hline Pasania kawakamii & Fagaceae & 3 & $0.86 \pm 0.04$ & $1.005 \pm 0.62$ & 14.0 & 15.0 & 26 & 49 & 34 \\
\hline Eriobotrya deflexa & Rosaceae & 7 & $0.88 \pm 0.13$ & $0.52 \pm 0.14$ & 13.5 & 20.0 & 19 & 49 & 29 \\
\hline Celtis formosana & Ulmaceae & 7 & $0.87 \pm 0.07$ & $0.62 \pm 0.14$ & 12.6 & 21.5 & 21 & 85 & 44 \\
\hline Cyclobalanopsis stenophlloides & Fagaceae & 1 & 0.77 & 0.76 & 12.0 & 12.0 & 28 & 28 & 28 \\
\hline Prunus campanulata. & Rosaceae & 1 & 0.75 & 0.44 & 11.0 & 11.0 & 55 & 55 & 55 \\
\hline \multicolumn{10}{|l|}{ Understorey } \\
\hline Viburnum arboricola & Caprifoliaceae & 2 & $0.74 \pm 0.10$ & $0.58 \pm 0.2$ & 10.0 & 10.0 & 39 & 42 & 40 \\
\hline Morus australis poir & Moraceae & 1 & 0.73 & 0.38 & 9.0 & 9.0 & 31 & 31 & 31 \\
\hline Turpinia formosana & Staphyleaceae & 6 & $0.60 \pm 0.17$ & $0.50 \pm 0.12$ & 7.3 & 16.5 & 23 & 91 & 44 \\
\hline Callicarpa formosana & Verbenaceae & 1 & 0.49 & 0.50 & 7.0 & 7.0 & 22 & 22 & 22 \\
\hline Tricalysia dubia & Rubiaceae & 1 & 0.69 & 0.40 & 7.0 & 7.0 & 26 & 26 & 26 \\
\hline
\end{tabular}
majority (60\% of all individuals) in the diameter class between 10 and $40 \mathrm{~cm}$ and shows a fast exponential

Table 2. Growth features of the most frequent tree species in Shenmu Broad-leaved Conservation Forest (SBCF)

${ }^{a}$ Values followed the symbol \pm indicate the stand deviation (SD) of the data while the other species have no SD due to no replication in the plot. 
Table 3. Correlation coefficients of structural and growth parameters over all individuals ${ }^{\mathrm{a}}$

\begin{tabular}{ccccc}
\hline & Height & DBH & Age & Wood Density \\
\hline Height & - & - & - & - \\
DBH & $0.47^{* *}(22 \%)$ & - & - & - \\
Age & $0.36 * *(13 \%)$ & $0.63^{* *}(40 \%)$ & - & - \\
Wood Density & $-0.07(0.7 \%)$ & $0.12(1 \%)$ & $-0.04(0.0 \%)$ & - \\
Radial growth & $0.33^{* *}(11 \%)$ & $0.30 * *(9 \%)$ & $-0.04(0.0 \%)$ & $0.02(0.0 \%)$ \\
\hline
\end{tabular}

asterisks indicate significance at $99 \%$ confidence level. In brackets R2 are given to explain the percentage of variability.

decrease.

Representatives of 4 species were found in the storey above $23 \mathrm{~m}$, with 18 species between 11 and $23 \mathrm{~m}$. The understory is most diverse with 5 different species.

The total basal area of living trees is $42.98 \mathrm{~m}^{2}$. F . formosana is dominating the stand in terms of basal area $\left(6.7 \mathrm{~m}^{2}\right)$ with only 23 individuals, mainly occurring in the highest crown layer with tree heights up to $30 \mathrm{~m}$ and a maximum DBH of $95 \mathrm{~cm}$. The tree with greatest dimensions is an Acer albopurpurascens with $140 \mathrm{~cm}$ $\mathrm{DBH}$ and $33 \mathrm{~m}$ height. M. zuihoensis is the most frequent species with 52 individuals, restricted to the understory with measured heights between 5 and $10 \mathrm{~m}$ and $\mathrm{DBH}$ valued between 13 and $30 \mathrm{~cm}$. The relation between diameter and height compared over all individuals is

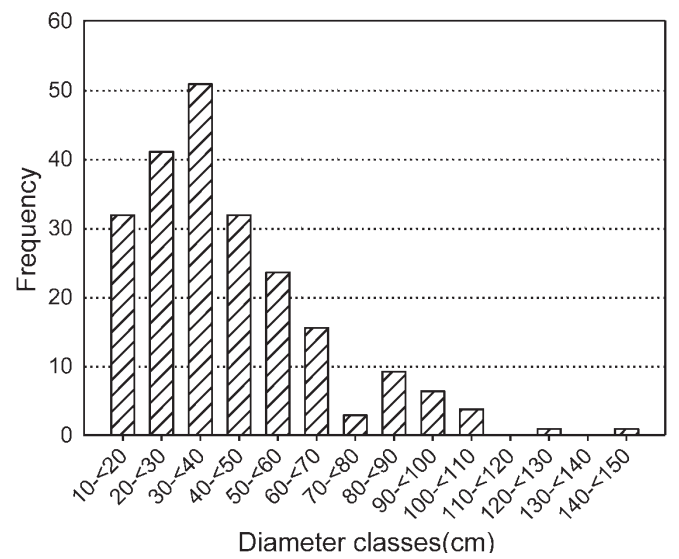

Fig. 3. $\mathrm{DBH}$ distribution of all trees with $\mathrm{DBH}>10 \mathrm{~cm}$ in the Shenmu Broad-leaved Conservation Forest in the plot $(n=218)$
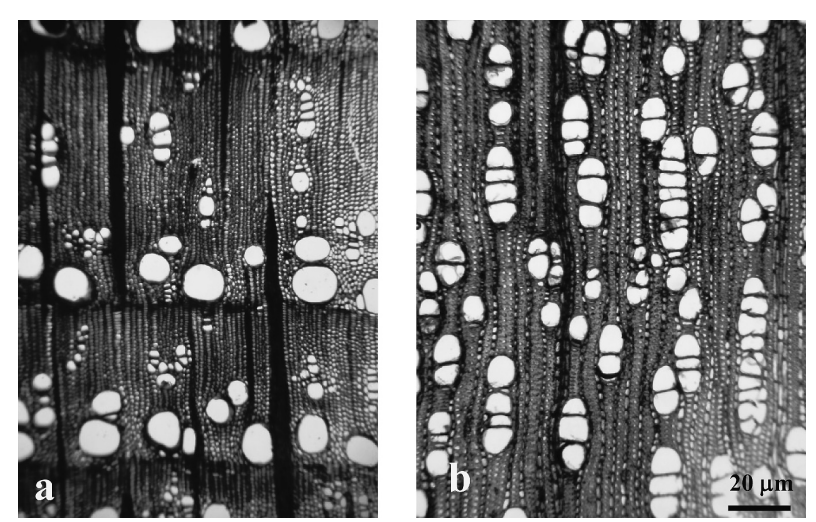

Fig. 4. The $F$. formosana (a) semi-ring pore wood and $M$. zuihoensis; (b) diffuse pore wood of cross section. close $\left(r^{2}=0.22\right.$, Table 3$)$.

\section{Annual tree rings in $M$. zuihoensis and other spe- cies}

On the highly resolution X-ray film the tree cores of growth zones appear specific differences in distinctiveness. All $F$. formosana and others show very clear rings, where, e.g. the growth zones of Celtis formosana on the cores are not distinguishable. Therefore, we do not include this species with two individuals in the calculation of growth rate. Distinct rings are delimited by marginal parenchyma as in F. formosana, M. zuihoensis (Fig. 4) and many others. Some researches show that the possibility to cross-date the time series of measured ring width is one indication of seasonal growth in tropical trees (Worbes, 1995; Stahle et al., 1999).

Despite the strong evidence of the described methods that tree ring at the investigated stand are annual in nature, we apply an additional method independent from the dendrochronological system by means of soft X-ray image analysis and CDedndro dating. This technique can easily find false and missing ring of the dominate species M. zuihoensi, B. erythrophloia and L. acuminata. An often used technique which may sometimes be very helpful is the comparison of information from local aged people whose age is almost or equal with the age of the trees or anything additional information that could be linked with the tree age and the number of tree rings.

\section{Wood density}

The wood density of a tree species is one indication of its life strategy. Pioneer trees generally have soft wood and trees of the mature forest show a low wood density (Swaine and Whitmore, 1988) often combined with high increment growth rates (Worbes, 1989). In the Shenmu broad-leaved conservation forest, wood densities vary between $0.49 \mathrm{~g} \mathrm{~cm}^{-3}$ for Callicarpa formosana and $0.94 \mathrm{~g}$ $\mathrm{cm}^{-3}$ for Zelkova formosana. Most trees of the upper storey have wood densities below $0.60 \mathrm{~g} \mathrm{~cm}^{-3}$ (e.g. A. formosana with $0.57 \mathrm{~g} \mathrm{~cm}^{-3}$ ). The majority of trees with high wood density are found in the main canopy. Some of these are restricted to the main canopy (e.g. Z. formosana: $\left.0.94 \mathrm{~g} \mathrm{~cm}^{-3}\right)$, whereas others like A. albopurpurascens $\left(0.92 \mathrm{~g} \mathrm{~cm}^{-3}\right)$ have representatives in all height classes (See Table 2). The mean for all individuals is $0.74 \mathrm{~g} \mathrm{~cm}^{-3}$. The density is below the value of a primary forest (V'arzea: $0.86 \mathrm{~g} \mathrm{~cm}^{-3}$ ) in the Amazonian inundation forest (Worbes, 1992). 


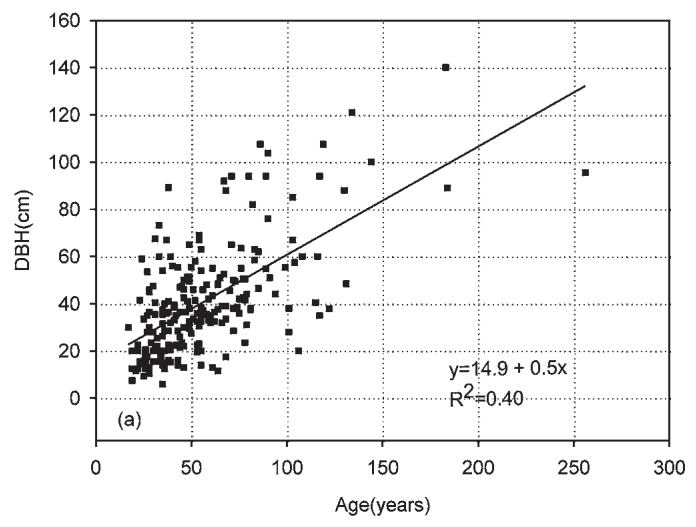

a

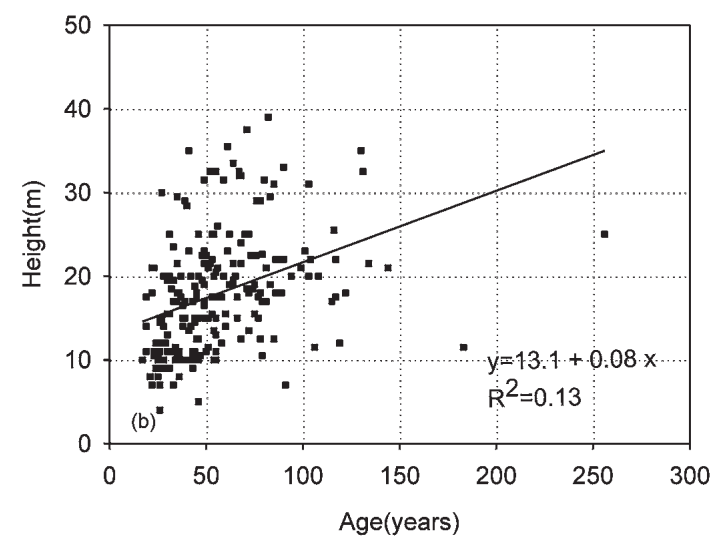

b

Fig. 5. (a) Diameter-age correlation of all age dated trees over $10 \mathrm{~cm}$ DBH in 0.71 ha of plot; (b) height-age correlation of all age dated trees over $10 \mathrm{~cm} \mathrm{DBH}$ in 0.71 ha of plot.

\section{Stand age structure}

The diameter of a tree is dependent on its age, but in a number of randomly selected individuals (e.g. in a diverse tropical forest site) it is not possible to correlate both parameters with sufficient for accuracy. The correlation between diameter and age is not very strong $\left(r^{2}=0.40\right.$, see Table 3$)$. Trees of the same age may have a diameter of 25 or $85 \mathrm{~cm}$ (Fig. 5a). For the trees calculated for all individuals in the plot, there is also no significant correlation between height and age. Results indicated in Fig. 5b show that trees with $35 \mathrm{~m}$ height may be 60 or 130 years old.

Though the shape parameters $(r)$ of both DBH and age distribution Weibull function indicate that they seem to be in medium status of forest regeneration, but the age's shape is much close to 1 , the limit boundary of very good status. The $53 \%$ of all individuals fall into this age range.

The age of the trees at the time of investigation varies considerably between species and within species between individuals (Table 2). The oldest tree is a C. camphora with 256 years, followed by a Diospyros morrisiana and A. albopurpurascens with 183-184 years. The youngest recorded tree was Fagara ailanthoides with 14 years. The maximum, minimum, and mean age of the

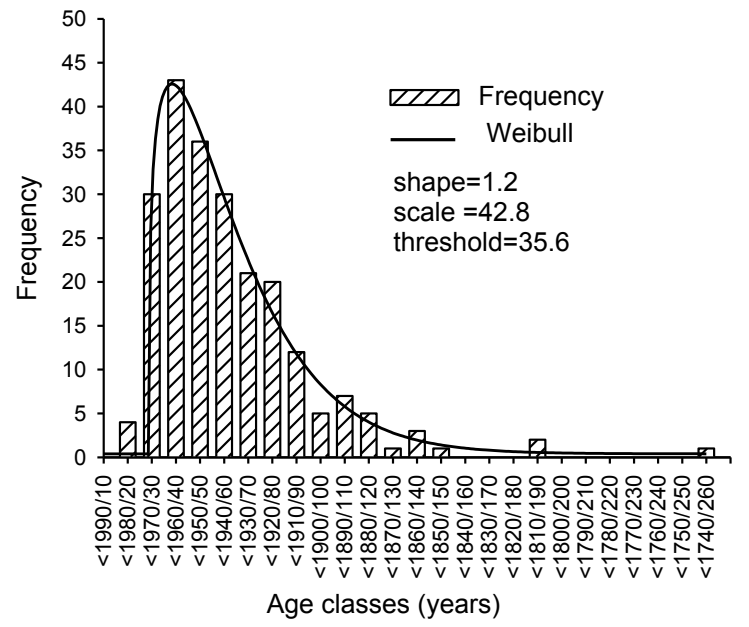

Fig. 6. Age classes distribution of all trees $\mathrm{DBH}>10 \mathrm{~cm}$ in 0.71 ha of Shenmu Broad-leaved Conservation Forest $(n=218)$.

most frequent species are given in Table 2.

Trees with an age of more than 115 years were found exclusively in the storey of the emergent (above $30 \mathrm{~m}$ ), the youngest tree of the upperstory is 22 years old ( $D$. morrisiana) and the mean age of the upper storey is 79 years.

Species cohorts are unevenly aged. The greatest difference in age between the youngest and the oldest individual within one species is found in C. camphora (188 years) and $D$. morrisiana (162 years).

A total of 218 living trees with a DBH greater than $10 \mathrm{~cm}$ were collected for analyzing the stand age, regeneration status, and growth competition in the natural forest stand. The age distribution of all individuals and simulated distribution of Weibull probability density function (pdf) is illustrated in Fig. 6. In order to examine all living tree the age distribution were used to simulate Weibull distribution. The average age of all trees of the stand is 61 years and the shape parameter of the Weibull probability distribution function is 1.2 as illustrated in Fig. 6 . It is an amazing and impressed phenomenon for the natural forest under moderate status of regeneration situation. Compared with the $\mathrm{DBH}(>10 \mathrm{~cm})$ distribution in Fig. 3, the shape factor of Weibull function will be 1.7 which is close to that of age distribution. It is implied that they may be very similar from the viewpoint of ecology.

\section{Diameter growth pattern}

The diameter growth rates of all individuals are listed in Table 2. The lowest values show the species of the understory (between 0.38 and $0.58 \mathrm{~cm}$ per year). Highest values occur in the main canopy (between $0.44-1.00 \mathrm{~cm}$ per year) and in emergent species (between $0.68-0.86 \mathrm{~cm}$ per year). The average for all individuals is $0.66 \mathrm{~cm}$ per year. The highest individual values were also found in upper storey trees (Pasania kawakamii: $1.00 \mathrm{~cm}$ per year, Z. ailanthoides: $0.98 \mathrm{~cm}$ per year, Cinnamomum insularimontanum: $0.94 \mathrm{~cm}$ per year). Lowest values were shown by Morus australis and Tricalysia dubia with 0.38 and $0.40 \mathrm{~cm}$ per year in the understory respec- 
tively.

The growth rates are correlated over all individuals positively with tree height (0.33) and the diameter at breast height (0.30). According to Table 3, both DBH and height are significantly correlated with tree age statistically while no correlation exists between mean growth rate and mean density of species is observable (0.02).

In contrast with the statement that "growth rates are fairly conservative over time" (Swaine and Putz, 1987), measured tree ring curves show a high variation year by year. This can be traced back to climate variations, in particular the variation for precipitation patterns between consecutive years as proved for T. scleroxylon in the investigation area (Staschel and Worbes, 1996). Similar findings derived from tree ring analysis are shown for Tectona grandis on Java (Berlage, 1931) and in Thailand (Pumijumnong and Eckstein, 1995). The variation year by year in subtropical trees is obviously higher than the variations observed in trees from the temperate zones.

In addition, different patterns of long-term growth trends can be observed in the investigated species. Typical examples are illustrated thereinafter. The first is an emergent F. Formosana reaches its ultimate and matures, and fast increase from the very young to a maximum followed by a decrease to a low level in the mature. During its later period of growth its increment decreases to a low standard (Fig. 7a). The second one, main canopy shade tolerant species $M$. zuihoensis, grows at small gaps during its early age and has very slow growth until it matured, when it emerges and its growth will then speed up (Fig. 7b). The third is a gap tree species $M$. Compressa, depending on the light conditions and gaps varied. The trees with one or more abrupt changes of the growth curve during their life span. Due to these reasons, it can be seen that the trace of release more or less increases relatively, and the tree ring width has a great range of varies. It speeds up in growing after its emergence (Fig. 7c). The fourth is an understory shade

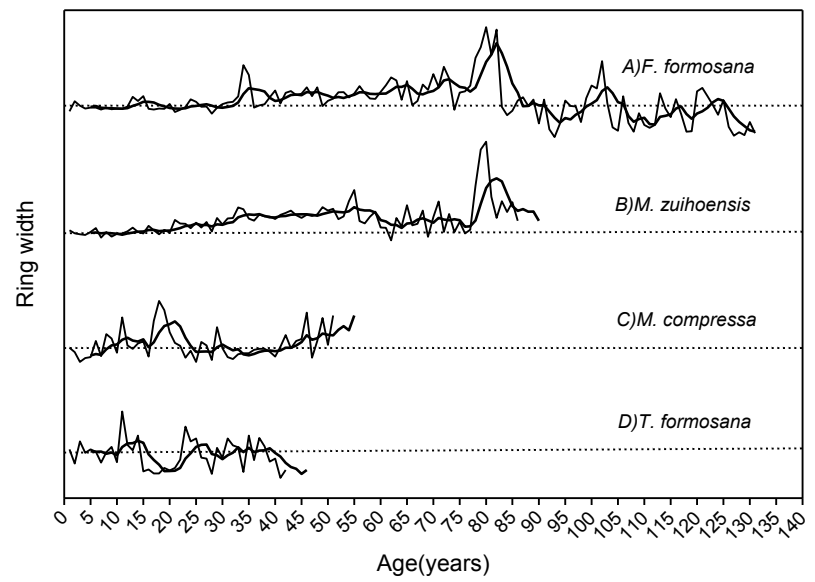

Fig. 7. Tree ring curves (solid line) of individual F. formosana $(\mathrm{n}=23), M$. zuihoensis $(\mathrm{n}=52), M$. compressa $(\mathrm{n}=8)$ and T. formosana $(\mathrm{n}=6)$ together with their trend curves (bold solid line is the five years moving average) showing different long-term trends. Dotted lines along each curves show the logarithmic scaled means of ring width. Growth changes among those during growth period are easier for comparison tolerant species T. Formosana, does not have distinct response to gaps. The trees increase more or less with a constant from the past to the present. Since its young period it adapts to gap changes until it matures, and then it slows down. It has a generally short life span (Fig. 7d).

The regeneration of species in a mature forest after gaps form can be divided into three growth pattern according to their variation during regeneration and their extent of shade tolerance that of climax species, pioneer species, and gap species (Su, 1984). Pioneers species and gap species require light condition between lager and small gaps to have more seedlings and grow well, whereas climax tree species needs merely small gaps and then gradually replaces the former two as the stand becomes crown closure. Afterwards, the existence of tree ring release subdivides the trees into main canopy shade tolerant species and understory shade tolerant species. Main canopy shade tolerant species such as B. erythrophloia, $M$. zuihoensis and $L$. acuminate are the major species forming the main canopy of this climax forest; the major understory shade tolerant species are T. formosana and $V$. arboricolum; Major gap species include $M$. compressa and $Z$. formosana, etc. and pioneers species includes $A$. formosana and $F$. formosana.

Within one species several growth patterns as defined above may occur. It results from the individual life history with respect to the given light conditions in any period of their life.

\section{DISCUSSION}

Since the concept of a general lack of annual rings in trees of tropical regions is still widely accepted in tropical ecology and forestry (Bruenig, 1996), estimation of growth rate and age in tropical forest trees were carried out by repeating diameter measurements (Clark and Clark, 1992; Korning and Balslev, 1994). More often these investigations cover only a short time period with respect to the age of a tree in natural forests. In the observed period either poor or good growth conditions may be present as a result of varying climate behavior. In addition, unidentified or dynamic reasons may influence the growth considerably. These trees are emergent and must have been grown faster in former times or be infinitely old. Our results, however, represent the radial increment over the life span of the trees. These data are interesting for foresters who want to plan the management for the entire tree, a species or a forest site.

The average of measured growth rate is $0.66 \mathrm{~cm}$ per year in SBCF. The comparison of these results done by researches mentioned above with our results must take into account that we include in our estimation not only the increments of the mature forest, but juvenile phases with higher growth rates. The values for canopy species in a Costa Rican forest with mean increment of $0.42 \mathrm{~cm}$ per year (Lieberman et al., 1985) less than our data from the main canopy in SBCF. The finding of all researches that overstory trees grow faster than understory trees is confirmed by our results. It is doubtless that the result 

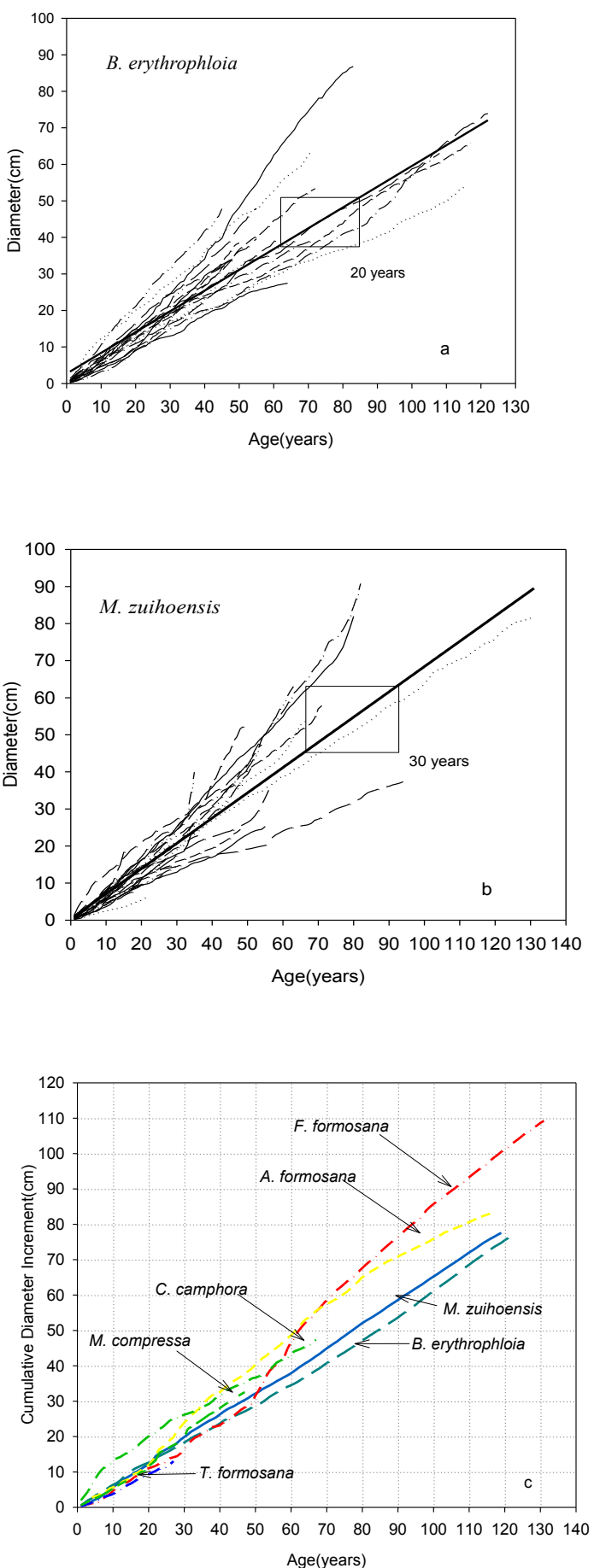

Fig. 8. (a) Individual and mean cumulative increment curves of B. erythrophloia $(\mathrm{n}=17)$ tree core. The box shows the time to pass 20 years for a mean stem. The minimum felling diameter is 50-60 cm; (b) Individual and mean cumulative curves of $M$. zuihoensis $(\mathrm{n}=25)$ tree core. The box shows the time to pass 30 years for a mean stem. The minimum felling diameter is $50-60 \mathrm{~cm}$. (c) The variation curve of cumulative diameter increment of the major species of relative positions of canopy strata and crown class. For examples: $F$. formosana $(\mathrm{n}=23), A$. formosana $(\mathrm{n}=8)$, and C. camphora $(\mathrm{n}=3)$ are emergents; $M$. compressa $(\mathrm{n}=5)$, M. zuihoensis $(\mathrm{n}=25)$, and B. erythrophloia $(\mathrm{n}=17)$ are upper conditions canopy species; $T$. formosana $(\mathrm{n}=5)$ is an understory species. of decreasing light saturation from the top to the ground of the forest.

In SBCF the minimum harvestable diameter for $B$. erythrophloia is laid down with $50-60 \mathrm{~cm}$. In the investigated stand trees it takes 85-95 years to grow into this diameter class; the mean is close to 90 years corresponding to a mean annual diameter increment rate of $0.68 \mathrm{~cm}$ (Fig. 8a). Besides, it takes about 20 years for tress to pass from 50 to $60 \mathrm{~cm} \mathrm{DBH}$. Other species M. zuihoensis grow much more slowly and will not reach $60 \mathrm{~cm}$ in diameter before an age of 90 years (Fig. 8b). In Zimbabwe, researchers found that the growth rate for the hardwood species Pterocarpus angolensis, measured with tree ring analysis, is much lower than ours due to the drier environment (Staschel et al., 1996). In total the growth rates in tropical or subtropical forests seem to be low. Plans for a sustainable management of these forests must consider that even the fastest growing timber species it also needs almost 90 years before they can be used commercially.

The result of our investigation and analysis prove that in a forest ecosystem, all tree species of biological characteristics have apparent variation in growth rate and pattern. Pioneers such as A. formosana and $F$. formosana are old growth. After the first 50 years of growth, their annual diameter increment becomes distinctly greater; after 100 years of growing, because of their emergence that makes them more disturbed by climate, they will have a variable annual increment. Main canopy shade tolerant species also have a long life span. In their young period, when their tree height has not yet reached the main canopy, their growth rate is low; later, when they reach the main canopy, they will grow abruptly. On the other hand, understory shade tolerant species have relatively slower growth rate and shorter life span. Their annual diameter increment, however, varies in accordance to stand site environmental changes.

The investigation of this study reveals that $F$. formosana, B. erythrophloia, and $M$. zuihoensis are the emergence and main canopy species in SBCF. Among them, $F$. formosana needs about 70 years to reach the fellable standard of $60 \mathrm{~cm}$ in DBH (Fig. 8c); its mean annual diameter growth rate is $0.86 \mathrm{~cm}$. Compared to pioneers and gap species, understory shade tolerant tree species have relatively lower mean annual diameter increments. T. formosana, a species of understory shade tolerant trees, has a mere $0.50 \mathrm{~cm}$ mean annual diameter increment. The growth rates of species are shown in (Fig. 8c). The main canopy tree species in SBCF apparently have much greater mean annual diameter growth rates than those in Costa Rica's tropical forest, which is only $0.42 \mathrm{~cm}$ (Lieberman et al., 1985). On the other hand, according to the age, height distribution and growth rate of the trees, we classify four major types of life strategies and growth pattern of specie cohorts. First species with young individuals and low increment rate in all age classes are generally restricted to the understory ( $T$. formosana). Second species with exclusively old individuals, high increment rates are restricted to the upper storey and can be classified as long-living pioneers (A. for- 
mosana). Third species with young and mature individuals which are dominated by young seedling low increment rate and mature tree high increment rate, along with one or more abrupt changes of the growth curve during their life span and can be classified as gap species ( $M$. compressa). Finally, species of some old individuals in the upper storey and many recruits in the lower canopy can be defined as mature forest trees or trees of the future (M. zuihoensis, B. erythrophloia, L. acuminata). These findings lead to the assumption that the investigated stand can be classified as a very late secondary stand in transition to a mature forest.

From the result of this study in SBCF, the use of tree ring analysis in subtropical evergreen forest ecology is a valuable tool for the interpretation of forest dynamics and for estimations of growth rate and pattern. Subtropical trees show a high variation in life history and a sensitive reaction to changing growth conditions. The increasing use of forests in the subtropics and the strong demand for a reliable database as the precondition for sustainable management planning, yet to be further developed by tree ring analysis, will provide an increase of ecological knowledge of these unique ecosystems.

\section{CONCLUSION}

The existence of annual rings in the wood of trees was proven by cross-dating and tree ring analysis. 218 individuals which belong to 27 species were investigated in the 0.71 ha plot of Shenmu evergreen broad-leaved forest. It shows that the age of the trees correlates not strongly with the diameter and the height, while the mean diameter growth rates vary between $0.48 \mathrm{~cm}$ per year in understory tree species and $0.76 \mathrm{~cm}$ per year in emergent species. The majority of the species (11) have more than five individuals in the study plot. The majority of the individuals belong to the understory up to 10-15 m. The $30 \%$ of the individuals form the main canopy between 17 and $25 \mathrm{~m}$ and $16 \%$ of all trees can be classified as emergents with tree height up to $25 \mathrm{~m}$. Representatives of 4 species were found in the storey above $23 \mathrm{~m}$, with 18 species between 11 and $23 \mathrm{~m}$. The understory is most diverse with 5 different species.

Stand of DBH and age structure fitted by Weibull function indicate that they are in medium status of forest regeneration, but the age's shape parameter $r=1.2$ is much close to 1 which stands for the limit boundary of very good regeneration status. The mean age for all individuals is 61 years. According to the age, height distribution and growth rate of the trees, we classify four major types of life strategies and the growth pattern of specie cohorts.

In the Shenmu broad-leaved conservation forest, wood densities vary between $0.49 \mathrm{~g} \mathrm{~cm}^{-3}$ for $C$. formosana and $0.94 \mathrm{~g} \mathrm{~cm}^{-3}$ for $Z$. formosana. Most trees of the upper storey have wood densities below $0.60 \mathrm{~g} \mathrm{~cm}^{-3}$. The majority of trees with high wood density are found in the main canopy. The mean for all individuals is $0.74 \mathrm{~g} \mathrm{~cm}^{-3}$. The oldest tree is a C. camphora with 256 years, followed by a $D$. morrisiana and A. albopurpurascens with 183-184 years. The youngest recorded tree was $F$. ailanthoides with 14 years. Trees with an age of more than 115 years were found exclusively in the storey of the emergent (above $30 \mathrm{~m}$ ), the youngest tree of the upperstory is 22 years old (D. morrisiana) and the mean age of the upper storey is 79 years. The greatest difference in age between the youngest and the oldest individual within one species is found in C. camphora (188 years) and D. morrisiana (162 years). The average age of all trees of the stand is 61 years.

The lowest values show the species of the understory (between 0.38 and $0.58 \mathrm{~cm}$ per year). Highest values occur in the main canopy (between $0.44-1.00 \mathrm{~cm}$ per year) and in emergent species (between $0.68-0.86 \mathrm{~cm}$ per year). The average for all individuals is $0.66 \mathrm{~cm}$ per year. The highest individual values were also found in upper storey trees (P. kawakamii: $1.00 \mathrm{~cm}$ per year, $Z$. ailanthoides: $0.98 \mathrm{~cm}$ per year, C. insularimontanum: $0.94 \mathrm{~cm}$ per year). Lowest values were shown by $M$. australis and T. dubia with 0.38 and $0.40 \mathrm{~cm}$ per year in the understory respectively.

The growth rates are correlated over all individuals positively with tree height (0.33) and the diameter at breast height (0.30). According to Table 3, both DBH and height are significantly correlated with tree age statistically while no correlation exists between mean growth rate and mean density of species is observable (0.02). These findings lead to the assumption that the investigated stand can be classified as a very late secondary stand in transition to a mature forest. The results also reveal that it is a valuable tool for estimations of growth rate and pattern by using tree ring analysis in subtropical evergreen forest ecology.

\section{REFERENCES}

Abrams M. D., Orwig D. A. and Demeo T. E., 1995 Dendroecological analysis of successional dynamics for a presettlement-origin white-pine-mixed-oak forest in the southern Appalachians, USA. J. Ecol., 83: 123-133

Amobi C. C., 1973 Periodicity of wood formation in some trees of lowland rainforest in Nigeria. Ann. Bot., 37: 211-218

Bailey R. L. and Dell T. R., 1973 Quantifying diameter distribution wit the Weibull function. For. Sci., 19: 97-104

Berlage H. P., 1931 Over het verband tusschen de dikte der jaarringen van djatiboomen (Tectona grandis L.f.) en den regenval op Java. Tectona, 24: 939-953

Bruenig E. F., 1996 Conservation and management of tropical rain forests, CAB international. Wallingford, UK.

Chan M. H., Wang Y. N. and Wang S. Y., 2004 Application of soft $\mathrm{X}$-ray image analysis to the width and density of tree-rings of Zelkova serrata, Cinnamomum camphora and Michelia compressa in natural forest. Quarterly Journal of Chinese Forestry, 37: 379-392

Clark D. A. and Clark D. B., 1992 Life history diversity of canopy and emergent trees in a Neotropical rainforest. Ecol. Monogr., 62: $315-344$

Ellenberg. H., 1986 Vegetation Mitteleuropas mit den Alpen, Ulmer. Stuttgart. p. 989

Koop H., 1989 Forest Dynamics: SILVI-STAR-A comprehensive monitoring system, Springer, Berlin. p. 242

Korning J. and Balslev H., 1994 Growth rates and mortality patterns of topical lowland tree species and the relation to forest structure in Amazonian Ecuador. J. Trop Ecol., 10: 151166 
Lang G. E. and Knight D. H., 1983 Tree growth, mortality, recruitment and canopy gap formation during a 10-year period in a tropical moist forest. Ecology, 64: 1075-1080

Lieberman D., Lieberman M., Hartshorn G. and Peralta R., 1985 Growth rates and age-size relationships of tropical wet forest trees in Cost Rica. J. Trop. Ecol., 1: 97-109

Lin C., Chan M. H., Chen F. S. and Wang Y. N., 2007 Age structure and growth pattern of an endangered species, Amentotaxus formosana Li. J. Integr. Plant Biol., 49: 157167

Msrisux. A., 1970 La periodicite de formation des cermes dans le bois de I'Okoume. Bios For. Trop., 131: 37-50

Msrisux A., 1981 Past effects in measuring age and annual growth in tropical trees. In: Bormann F. H. Berlyn G. (Ed.), Age and Growth Rate of Tropical Trees: New Directions for Research, Ysle University Press, New Haven, pp. 20-30

Pumijumnong N., Eckstein D. and Sass U., 1995 Tree ring research in Tectona grandis in northern Thailand. IAWA J., 16: $385-392$

Stahle D. W., Mushove P. T., Cleaveland M. K., Roig F. and Haynes G. A., 1999 Management implications of annual growth rings in Plerocarpus angolensis from Zimbabwe. For. Ecol. Manage., 124: 217-229

Staschel, R., Worbes. M. and Roloff. A., 1996 Wachstumsdynamik von Triplochiton scleroxylon (K. Schum.) in einem halbir- mer-grunen Naturwald in Kamerun. Verhandlungen der Gesellschaft fur Okologie, 26: 183-188

Su H. J. 1984 Studies on the climate and vegetation type of the natural forest in Taiwan: (II) Altitudinal vegetation zones in relation to temperature gradient. Quarterly Journal of Chinese Forestry, 17: 57-73 (in Chinese)

Swaine M. D. and Putz. F. E., 1987 The dynamics of tree populations in tropical forests: a review. J. Trop. Ecol. Bois For. Trop., 3: 359-369

Swaine M. D. and Whitmore T. C., 1988 On the definition of ecological species groups in tropical rain forests. Vegetation, 75: $81-86$

Tanouchi H. and Yamamoto S., 1995 Structure and regeneration of canopy species in an old-growth evergreen broad-leaved forest in Aya district, southwestern Japan. Vegetation, 117: 51-60

Whitmore T. C., 1990 An introduction to tropical rain forests, Oxford University Press, Oxford, p. 296

Worbes M., 1989 Growth rings, increment and age of trees in inundation forests, Savannas and a mountain forest in the Neotropics. IAWA Bull. n.s., 10: 109-122

Worbes M., 1992 Occurrence of seasonal climate and tree ring research in the tropics. Lundqua Rep., 34: 338-342

Worbes M., 1995 How to measure growth dynamics in tropical trees -a review, IAWA J., 16: 337-351 